\title{
PG E2 GEL SUPPLEMENTED WITH ORAL PG E2 FOR INDUCTION OF LABOUR IN HIGH RISK PREGNANCY
}

\author{
Doshi N.R. ${ }^{1}$, Sah D. ${ }^{2}$, Das C.R. ${ }^{3}$
}

\section{ABSTRACT}

INTRODUCTION : The risks to the fetus-infant increase substantively in high risk pregnancies. The efforts are always to ensure a vaginal rather than a caesarian delivery. The present study aims to assess the safety and efficacy of Prostaglandin E2( PGE2) intracervical gel and oral PGE2 in inducing and augmenting labour in such patients.

METHODS: PGE2 intracervical gel was used for induction of labour in 100 high risk pregnancies. PGE2 gel was supplemented by oral PGE2 afterARM.

RESULTS: PGE2 successfully induced labour in 60\% of women while it improved the Bishop's score in the rest of the cases. L.S.C.S. was needed in only $7 \%$ of women.

CONCLUSION: Intracervical PGE2 gel application is a safe and efficacious method of inducing labour, which can be augmented with oral PGE2 when needed.

KEYWORDS: Prostaglandin E2 gel, Oral PGE2, High risk pregnancy, Induction of labour.

1. Associate Professor, Department of Obstetrics \& Gynaecology, Universal College of Medical Sciences \& Teaching Hospital, Bhairahawa, Nepal

2. Assistant Professor, Department of Obstetrics \& Gynaecology, Janaki Medical College \& Teaching Hospital, Janakpur, Nepal

3. Professor, Department of Obstetrics \& Gynaecology, Nepalgunj Medical College \& Teaching Hospital Kohalpur, Nepal

For Correspondence

Dr. Nilesh R. Doshi,

Associate Professor,

Department of Obstetrics \& Gynaecology,

Universal College of Medical Sciences \& Teaching Hospital,

Bhairahawa, Nepal

E-Mail: docnileshdoshi@yahoo.com 


\section{INTRODUCTION}

Elective induction of labour in high risk pregnancies is always desired to ensure satisfactory perinatal outcome. The cervix is often unfavourable in these cases at the time of induction and this presents a great challenge in the successful induction of labour. ${ }^{2-5}$ Recently prostaglandins have revolutionised the labour induction techniques, especially in those patients with unfavourable cervical conditions. Efforts are still on to find the best route for it's administration and the role of PGE2 in augmentation of labour. ${ }^{6}$ The present study was undertaken to investigate:

1) Effectivity of cervical application of PGE2 gel as an inducing agent.

2) Role of oral PGE2 as an augmenting agent after priming the cervix with PGE2 gel.

\section{MATERIAL AND METHOD}

One hundred pregnant women with one or more high risk factors were selected from the admitted patients for induction of labour at Nepalgung Medical College Teaching Hospital Kohalpur between june 2010 and december 2011. The criteria for selection of cases were:

1) Gestational age $>36$ weeks with cephalic presentation and intact membranes.

2) Parity between 04

3) Singleton pregnancy

Exclusion criteria:

1) Previous uterine and / or urinary bladder surgery.

2) Placenta previa in current pregnancy.

3) Intra uterine fetal demise.

4) Hypersensitivity to prosrtaglandins.

Gel application:

After detailed ultasonic examination, informed consent was taken. Bishop's score was determined and pelvic assessment was done. When the pelvis was found to be adequate, $0.5 \mathrm{mg}$ PGE2 in $2.5 \mathrm{ml}$ of gel was instilled in the cervical canal. Patient was kept in recumbent position for 30 minutes and was monitored for uterine contractions, fetal heart rate and vital signs every $1 / 2$ hourly for 6 hours. Monitoring was continued as for active labour, if labour supervened in this period.

Oral PGE2 administration for augmentation of labour:

In those patients who did not go into active labour, Bishop's score was reassessed after 12 hours, ARM was done and $0.5 \mathrm{mg}$ PGE2 per hour was administered orally. If labour pains were not induced within 4 hours then the dose of oral prostaglandins was doubled to $1 \mathrm{mg}$ per hour. The dose was reduced to $0.5 \mathrm{mg}$ once the patient was in active labour and continued till delivery.

\section{RESULTS}

The age of the selected patients ranged between 19 to 38 years. The mean age was $24.80+/-4.14$ years. Sixty one $(61 \%)$ were primigravidae and $39 \%$ were multigravida. The majority $(23 \%)$ of these multiparas were second gravidae. The mean period of gestation at the time of induction was 38 weeks 5 Days $+/-1.52$ weeks. The mean pre-induction Bishop's score was $4.56+/-1.56$. In primigravidas the mean Bishop's score was $4.4+/-1.5$ (42 primis had unfavourable cervix while 19 had favourable cervix. In multigravidae (39\%) mean Bishop's score was $4.67+/-1.58$ and 25 of these had unfavourable cervix prior to application of gel. The indications for induction are listed in table 1. The most common were PIH $(27 \%)$ and IUGR (25\%). in $22 \%$ there were more than one indications.

\section{Table 1: Indications for induction of labour}

\begin{tabular}{|l|l|l|}
\hline \multicolumn{1}{|c|}{$\begin{array}{c}\text { Indication } \\
\text { for Induction }\end{array}$} & $\begin{array}{r}\text { No (\%) of patients } \\
\text { with } \\
\text { one indication. }\end{array}$ & $\begin{array}{r}\text { No of patients with } \\
\text { more } \\
\text { than one indication }\end{array}$ \\
\hline PIH & $27(27 \%)$ & 14 \\
\hline IUGR & $25(25 \%)$ & 19 \\
\hline BOH & $10(10 \%)$ & 03 \\
\hline Post- Term Pregnancy & $09(09 \%)$ & 05 \\
\hline Elderly Primigravida & $04(04 \%)$ & 03 \\
\hline Essential Hypertension & $03(03 \%)$ & 03 \\
\hline Total & $\mathbf{7 8 ( 7 8 \% )}$ & $\mathbf{4 7 *}(\mathbf{2 2 \% )}$ \\
\hline
\end{tabular}

*Thirteen cases had 3 indication, 19 cases had 2 indications.

Seventy two percent patients started having labour pains within 4 hours of gel application and 60\% (31) primigravida and 29 multigravida) progressed into active labour and had normal unassisted vaginal delivery within 24 hours. Thirty one $(31 \%)$ of these delivered within 12 hours. The mean instillation delivery interval was 10 hours 32 minutes $(10.55+/-3.48$ hours $)$. The corresponding intervals for primigravidae and multigravidae were 11 hours 21 minutes and 9 hours 40 minutes respectively. One patient $(1 \%)$ had cervical tear due to uterine 
hypertonicity. (The total duration of labour in this case was 5 hours 05 minutes and second and third stages of labour were less than 5 minutes each.) Augmentation with oral prostaglandins.

Forty percent of patients $(30$ primigravida and 10 multigravida) who did not go into active labour with prostaglandin gel had reassessment of Bishop's score after 12 hours and the mean Bishop's score had increased from 4.5 to 7.4 in these cases.

Table 2: Change in Bishop's score 12 hours after PGE2 application

\begin{tabular}{|l|l|l|l|}
\hline \multirow{2}{*}{ Author } & \multirow{2}{*}{ No of Patients } & \multicolumn{2}{c|}{ Mean Bishop Score } \\
\cline { 3 - 4 } & & $\begin{array}{c}\text { Before gel } \\
\text { application }\end{array}$ & $\begin{array}{c}\text { After gel } \\
\text { application }\end{array}$ \\
\hline Theiry et al. $^{2}$ & 40 & 3.4 & 6.6 \\
\hline Patki et al. $^{7}$ & 40 & 2.6 & 5.0 \\
\hline Daftary et al. $^{8}$ & 60 & 3.2 & 7.6 \\
\hline Present study & 100 & 4.5 & 7.4 \\
\hline
\end{tabular}

Labour was augmented with oral PGE2 after ARM. The mean dose of oral PGE2 required to complete the labour was $4.30 \mathrm{mgm}$. The maximum single dose of $1 \mathrm{mg}$ per hour was required in only $2(5 \%)$ of cases. The mean period of onset of labour was 53 minutes. It was 49 minutes in primiparas and 63 minutes in multigravidas. Thirty-three $(82.5 \%)$ of the 40 patients whose labour was augmented with oral PGE2 had vaginal deliveries, 7 $(17.5 \%)$ of these were forceps assisted deliveries. The mean IDI (Induction Delivery Interval) was $8.34+/ \ldots 3.04$ hours (Range: 2 hours 50 minutes to 15 hours 48 minutes). The mean IDI in primigavidae $(24$ cases) was 7 hours 08 minutes and in multigravidae (9 cases) was 6 hours. Caesarean delivery rate was $17.5 \%$ (7 patients) and the indications for caesarean section were foetal distress (1 case), non progress of labour (5 cases), deep transverse arrest ( 3 cases) and uterine inertia (3 cases). Both factors were co-existing in another case who had a thick septum between the presenting part and the internal os.

The mean Apgar score at 1 and 5 minutes was $6.5+/-1.2$ aaand $8.4+/-1.1$ respectively. The mean birth weight was 2657 gms +/- 440 gms. Seven (7\%) patients experienced nausea and vomitting but were self limiting in all of these cases. There was one (1\%) neonatal death on the $4^{\text {th }}$ post natal day. The Apgar score was 2 at 1 minute in this case and the baby was resuscitated with endotracheal intubation. One $(1 \%)$ patient had uterine hypertonus.
Overall failure rate (caesarean section) was 7\% (Table 3).

Table 3: Labour outcome after induction with prostaglandins

\begin{tabular}{|l|l|l|l|l|}
\hline \multicolumn{1}{|c|}{ Author } & $\begin{array}{c}\text { No of } \\
\text { cases }\end{array}$ & $\begin{array}{c}\text { No of cases } \\
\text { delivered } \\
\text { vaginally }\end{array}$ & $\begin{array}{c}\text { No of } \\
\text { C.S. }\end{array}$ & $\begin{array}{c}\text { \% of } \\
\text { C.S. }\end{array}$ \\
\hline Daftary et al. $^{8}$ & 60 & 48 & 12 & $20 \%$ \\
\hline Nimrod et al. $^{9}$ & 15 & 14 & 01 & $6.6 \%$ \\
\hline Freeney et al. $^{10}$ & 126 & 108 & 18 & $14.3 \%$ \\
\hline Present study $^{2}$ & 100 & 93 & 07 & $7 \%$ \\
\hline
\end{tabular}

\section{DISCUSSION}

Calder AA and Trofatter KF suggested that the local application of prostaglandins was an effective method of induction of labour. ${ }^{11}{ }^{12}$. Ulmsten et al. found that the endo-cervical application of PGE2 gel was safe, had minimal side efects with negligible incidence of uterine hypertonus. ${ }^{13}$ Daftary etal. observed that cerviprime gel is an effective inducing agent and when coupled with oral PGE2 it is effective in maintaining the progress of labour. ${ }^{8} \quad$ In the present study cervical application of PGE2 gel acted as an inducing agent in $60 \%$ of total induced patients. In the remaining $40 \%$ of patients the Bishop's score improved from 4.5 to 7.4 in our study, whereas Daftary et al. reported an improvement from 3.2 to 7.6 in the same period (12 hours) as that of the present study. ${ }^{8}$ The incidences of sucessful inductions in previous studies were $60 \%$ (Nimrod et al.), $43.3 \%$ (Daftary et al.) and $73 \%$ (Freeney et al.). ${ }^{8-10}$ The pre induction Bishop's scores in the studies of Nimrod et al. and Freeney et al. were $<4$ and it was 3.2 in the study by Daftary et al. while in the present study the mean Bishop's score was $4.5^{8-10}$

Labour was augmented with oral PGE2 after ARM and $33(82.5 \%)$ of the remaining 40 women delivered vaginally with a mean IDI of 7 hours 21 minutes which is close to the IDI of 7 hours and 51 minutes reported by Patki etal. ${ }^{7}$ Only $7(17.5 \%)$ of the remaining 40 women needed caesarean sections in emergency which compares favourably with $12(35.3 \%)$ of 34 patients in the study by Daftary et al. ${ }^{8}$ The mean dose of oral PGE2 required for augmentation of labour was $4.30 \mathrm{mgm}$ as compared to $3 \mathrm{mgm}$ reported by Daftary et al. ${ }^{8}$ The overall caesarean section rate in our study was $7 \%$ 
(Table 4) which compares well with $6.6 \%$ C.S. rate reported by Nimrod etal and is much lesser than $20 \%$ reported by Daftary et al. 8.9 .

Table 4: IDI with PGE2 gel \& after augmentation with oral PGE2

\begin{tabular}{|l|l|l|l|}
\hline & Primigravida & Multigravida & Overall ( \% ) \\
\hline Total no. of patients & 61 & 39 & 100 \\
\hline Delivered within 12 hrs. of gel appln. & 18 & 21 & $39(39 \%)$ \\
\hline Delivered within 24 hrs of gel appln. & 13 & 08 & $21(21 \%)$ \\
\hline Mean IDI & 11 hrs. 21 mins. & 9 hrs. 40 mins. & 10 hrs. 32 mins. \\
\hline Augmented with ARM \& PGE2 & 30 & 10 & $40(40 \%)$ \\
\hline Onset of labour after ARM + oral PGE2 augmentation & 49 mins. & 63 mins. & 53 mins. \\
\hline IDI after ARM \& oral PGE2 & 8 hrs. 52 mins. & 6 hrs. 05 mins. & 7 hrs. 21 mins. \\
\hline Total normal vaginal deliveries & 48 & 38 & $86(86 \%)$ \\
\hline Total forceps vaginal deliveries & 07 & -- & $07(07 \%)$ \\
\hline Total Caesarean Sections & 06 & 01 & $07(07 \%)$ \\
\hline Total complications & 05 & 03 & $08(08 \%)$ \\
\hline
\end{tabular}

The complication rate was $8 \%(7 \%$ had nausea and vomitting while $1 \%$ had uterine hypertonus ) which is significantly low when compared to $35 \%$ gastrointestinal symptoms and $5 \%$ uterine hypertonus reported by Daftary et al. in their study. ${ }^{8}$ One perinatal death ocurred in the present study.

\section{CONCLUSION}

Intra cervical PGE2 gel application is a convenient, acceptable, safe and effective method of induction of labour in high risk cases apart from its conventional role as a cervical ripening agent. Besides labour can be sucessfully augmented after ARM with oral administration of PGE2 instead of IV oxytocin infusion.

\section{REFERENCES}

1. Rayburn WF, Wood R, Ramadei C. Intra-vaginal Prostaglandin E 2 gel and cardiovascular changes in hypertensive pregnancies. Am J Perinatol. $1991 \mathrm{Jul} ; 8(4): 233-5$.

2. Thiery $M$, Decoster JM, Parewijk W, Noah ML, Derom $R$, $V n$ Kets $H$ et al. Endo-cervical Prostaglandin E2 gel for pre induction cervical softening. Prostaglandins. 1984 Mar; 27(3): 429-39.

3. Wingerup L, Andersson KE, Ulmsten U. Ripening of the uterine cervix and induction of labour at term with Prostaglandin E2 in viscous gel. Acta Obstet Gynecol Scand. $1978 ; 57(5): 403-6$

4. Rayburn WF. Prostaglandin E2 gel for cervical ripening and induction of labour : a critical analysis. Am J Obstet Gynecol. 1989 Mar; 160(3): 529-34.
5. Veena, Saxena K, Singhal KC. Evaluation of PGE2 gel for cervical ripening and induction of labour. Indian $J$ Phsiol Pharmacol. $1994 \mathrm{Jul} ;$;8(3):93-6.

6. Nuutila $M$, Kajanoja P. Local administration of Prostaglandin E2 for cervical ripening \& labor induction : the appropriate route and dose. Acta Obstet Gynecol Scand. $1996 \mathrm{Feb} ; 75(2): 135-8$.

7. Patki A, More S, Lenka S, Ganta K, Desai S. Labour induction - oxytocin vs PGE2. J Obstet Gynecol India. 1993 Jan; 43(1): $92-8$.

8. Daftary GS, Levi JM, Dftary SN. Prostaglandin E2 gel induction and augmentation of labour. J Obstet Gynecol India. $1994 \mathrm{Apr} ; 44(2): 63-72$.

9. Nimrod C, Currie J, Yee J, Dodd G, Persaud D. Cervical ripening and labour induction with intra-cervical PGE2 gel : a placebo controlled study. Obstet Gynecol. 1984 Oct, 64(4) : 476-9.

10. Freeney JG, Basu SB. PGE2 gel as a routine method of labour induction. Ir Med J. 1981 Mar;74(3):93-4.

11. Calder AA. Prostaglandin therapy for labour induction. Reprod Fertil Dev. 1990; 2(5) : 553-6.

12. Trofatter KF. Endocervical Prostaglandin E2 gel for preinduction cervical ripening. J Reprod Med. 1993 Jan; 38 (1 suppl) : 78-82.

13. Ulmsten U, Wingerup L, Ekman G. Local application of Prostaglandin E2 for cervical ripening or induction of term labour. Clin Obstet Gynecol. 1983 Mar; 26(1):95-105. 